\title{
Clinical features of dengue hemorrhagic fever and risk factors of shock event
}

\author{
Rismala Dewi, Alan Roland Tumbelaka, Damayanti Rusli Sjarif
}

\begin{abstract}
Background Dengue hemorrhagic fever (DHF) can lead to high morbidity and mortality. Its clinical features vary from time to time. Many studies were performed to determine the risk factors of severe dengue infection.

Objective To find out clinical features and risk factors for predicting the likelihood of shock in DHF.

Methods A retrospective cohort study was conducted in all confirmed DHF children who were hospitalized at the Department of Child Health, Cipto Mangunkusumo Hospital within the period of January 1, 2003 until June 30, 2004. Risk factors for development of shock were analyzed using chi-square test and multiple logistic regressions with a level of significance of $<0.05$.

Results A total of 101 patients, consisted of 47 males and 54 females were enrolled in this study. Mean age was 6.5 (SD 3.6) years, ranged from 5 months to 15 years. About $31.7 \%$ patients had grade III DHF, $30.7 \%$ grade II, and $26.7 \%$ grade IV (including 1 patient with encephalopathy). Shock was more frequent among patients aged between 6-10 years, female, under-nourished, body temperature $<38^{\circ} \mathrm{C}$, hematocrit level $46-50$ vol\%, and platelet count $<20000 / \mathrm{ml}$. During year 2003-2004, there was increased number of patients who developed shock. Based on univariate analysis, hepatomegaly, high hematocrit value, and thrombocytopenia were considered significantly different. Among those variables analyzed with multiple logistic regression method, only hepatomegaly and thrombocytopenia were identified as predictors of shock.

Conclusion There was an alteration on clinical features of DHF in our hospital in 2003-2004 period compared to the previous years. Hepatomegaly and platelet count $<50000 / \mathrm{ml}$ are independent risk factors of shock among DHF patients [Paediatr Indones 2006;46:144-148].
\end{abstract}

Keywords: Dengue hemorrhagic fever in children, clinical features, risk factor, dengue shock syndrome

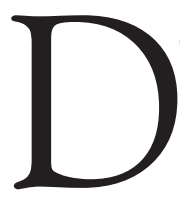
engue hemorrhagic fever (DHF) is one of the leading causes of morbidity and mortality in children in many Southeast Asian countries. ${ }^{1-4}$ In Indonesia, DHF epidemic occurs every year with expansion of epidemic areas and its incidence tends to increase. ${ }^{5}$ Early clinical diagnosis of dengue virus infection can be difficult, especially in recognizing the early stage of the patients who will ultimately develop shock. The mortality of shock cases was 3 to 10 times higher compared to that of non-shock group. Nevertheless, the severity of shock syndrome depends on the pathogenesis of the disease. ${ }^{6-10}$

Many aspects of DHF have been studied to find out the risk factors that play important roles in determining severity of dengue virus infection. ${ }^{11-15} \mathrm{~A}$ few studies on risk factors of shock development has been performed in Jakarta, Bali, and Yogyakarta with different variables and results. ${ }^{16-18}$ Every ten-year observation in Cipto Mangunkusumo Hospital, Jakarta showed alteration of the symptoms of dengue virus infection between each period. ${ }^{6}$ The objective of our study was to find out the clinical features of DHF in the Department of Child Health Cipto Mangunkusumo Hospital.

From the Department of Child Health, Medical School, University of Indonesia, Jakarta, Indonesia.

Reprint requests to: Rismala Dewi, MD, Department of Child Health, Medical School, University of Indonesia, Cipto Mangunkusumo Hospital, Jl. Salemba 6, Jakarta, Indonesia. Tel. 62-21-3907742. Fax. 62-21-3907743. Email: rismalahary@yahoo.com 


\section{Methods}

A retrospective cohort study was carried out in all DHF children who were hospitalized in Department of Child Health, Cipto Mangunkusumo Hospital between January 1, 2003 and June 30, 2004. Enrollment criteria were all children who met WHO criteria and underwent dengue duo $\operatorname{IgM}-\operatorname{IgG}$ rapid strip serological tests (sensitivity $90 \%$, specificity $86 \%$ ). Patients with positive result for IgM alone or both IgM/ IgG were followed up for clinical profile, laboratory findings, and risk factors. Data were taken from medical records written by residents in charge. Patients with incomplete data were excluded.

Sample size was estimated according to "rule of thumb", i.e. 10 patients for every 1 independent variable, resulting the minimal sample size of 90 . Univariate and multiple logistic regression analyses and calculation of relative risk (RR) were performed to find any association among the nine risk factors with the development of shock. All statistic procedures were done on SPSS 10.00 for Windows program. The study was approved by the Committee for Medical Research Ethics of the Faculty of Medicine, University of Indonesia.

\section{Results}

During study, there were 263 children who were diagnosed as DHF, but only 146 children underwent dengue duo IgM-IgG rapid strip serological tests. Based on inclusion criteria, there were 101 children included in this study. Forty-two of these 101 patients were categorized as having non-shock DHF (grade I, 11 patients; grade II, 31 patients) and 59 were categorized as having DSS (grade III, 32 patients; grade IV, 27 patients). Most cases (44\%) were 6-10 years of age [mean 6.5 (SD 3.6) years; ranged from 5 months to 15 years). Male to female ratio was nearly equal, 1:1.1. Characteristics of subjects are shown in Table 1.

Mean maximum temperature among DHF patients was $38.2^{\circ} \mathrm{C}\left(\mathrm{SD} 1.1\right.$; range $36.5^{\circ} \mathrm{C}$ to $\left.41^{\circ} \mathrm{C}\right)$. The duration of fever before admission and shock event were 4 days (mean 4.3; SD 0.9) and 5 days (mean 4.6; SD 0.7 ), respectively. Shock was found more frequently in male and female with low nutritional status, temperature $<38^{\circ} \mathrm{C}$, hematocrit value $46-50 \mathrm{vol} \%$, and plate-
Table 1. Characteristics of Subjects

\begin{tabular}{|c|c|c|c|c|c|c|}
\hline \multirow[t]{2}{*}{ Variable } & \multicolumn{2}{|c|}{ Shock (+) } & \multicolumn{2}{|c|}{ Shock (-) } & \multicolumn{2}{|c|}{ Total } \\
\hline & $n$ & $(\%)$ & $\mathbf{n}$ & $(\%)$ & $\mathbf{n}$ & $(\%)$ \\
\hline \multicolumn{7}{|l|}{ Age (years) } \\
\hline$<1$ & 2 & 2 & 2 & 2 & 4 & 4 \\
\hline $1-5$ & 23 & 23 & 13 & 13 & 36 & 36 \\
\hline $6-10$ & 29 & 29 & 15 & 14 & 44 & 44 \\
\hline $11-15$ & 5 & 5 & 12 & 12 & 17 & 17 \\
\hline 15 & 0 & 0.0 & 0 & 0.0 & 0 & 0.0 \\
\hline \multicolumn{7}{|l|}{ Sex } \\
\hline Female & 33 & 33 & 21 & 21 & 54 & 54 \\
\hline Male & 26 & 26 & 21 & 21 & 47 & 47 \\
\hline \multicolumn{7}{|l|}{ Nutritional status } \\
\hline Overweight & 3 & 3 & 4 & 4 & 7 & 7 \\
\hline Normal & 19 & 19 & 14 & 14 & 33 & 33 \\
\hline Under-nutrition & 37 & 37 & 24 & 24 & 61 & 60 \\
\hline Severe malnutrition & 0 & 0 & 0 & 0.0 & 0 & 0.0 \\
\hline \multicolumn{7}{|l|}{ Temperature $\left({ }^{\circ} \mathrm{C}\right)$} \\
\hline$<38$ & 34 & 34 & 17 & 17 & 51 & 51 \\
\hline $38.1-39$ & 15 & 15 & 14 & 14 & 29 & 29 \\
\hline $39.1-40$ & 7 & 7 & 10 & 10 & 17 & 17 \\
\hline$>50$ & 3 & 3 & 1 & 1 & 4 & 4 \\
\hline \multicolumn{7}{|l|}{ Hematocrit (vol\%) } \\
\hline$<40$ & 10 & 10 & 15 & 15 & 25 & 25 \\
\hline $40-45$ & 20 & 20 & 19 & 19 & 39 & 39 \\
\hline $46-50$ & 21 & 21 & 7 & 7 & 28 & 28 \\
\hline$>50$ & 8 & 8 & 1 & 1 & 9 & 9 \\
\hline \multicolumn{7}{|l|}{ Platelet count $(\mu / \mathrm{l})$} \\
\hline$<20000$ & 32 & 32 & 6 & 6 & 38 & 38 \\
\hline $20-50000$ & 22 & 22 & 12 & 12 & 34 & 34 \\
\hline $51-100000$ & 5 & 5 & 18 & 18 & 23 & 23 \\
\hline$>100000$ & 0 & 0.0 & 6 & 6 & 6 & 6 \\
\hline Total (n/\%) & 59 & 58 & 42 & 42 & 101 & 100 \\
\hline
\end{tabular}

let count $<20000 / \mu$ l. Petechie was the most common bleeding manifestation in DHF grade II to IV, while melena was found only in DHF grade IV.

Clinical spectrum of DHF seems to be altered every ten-year observation. There was increasing number of symptoms of shock, thrombocytopenia, vomiting and diarrhea, while the number of abdominal pain, hepatomegaly, and bleeding manifestation decreased. In the present study, the most common presentations were fever (100\%), thrombocytopenia (94\%), hemoconcentration $(86 \%)$, petechie $(70.4 \%)$, and vomiting (66.3\%) (Table 2).

Using univariate analysis we found that the presence of hepatomegaly, hematocrit $\geq 41.5 \mathrm{vol} \%$, and platelet count $<50000 / \mathrm{ml}$ significantly correlated with shock event. There were no statistically significant differences in age, sex, nutritional status, abdominal pain, and leukocyte count between both groups (Table 3).

Multiple logistic regression analysis showed that only hepatomegaly and platelet count $<50000 / \mathrm{ml}$ correlated with the incidence of shock. (Table 4). 
Paediatrica Indonesiana

Table 2. Clinical spectrum of dengue hemorrhagic fever

\begin{tabular}{lcccc}
\hline \multicolumn{1}{c}{ Symptoms } & $\begin{array}{c}\mathbf{1 9 7 5 - 1 9 7 8} \\
\mathbf{( \% )}\end{array}$ & $\begin{array}{c}\mathbf{1 9 8 5 - 1 9 8 6} \\
\mathbf{( \% )}\end{array}$ & $\begin{array}{c}\mathbf{1 9 9 3 - 1 9 9 5} \\
\mathbf{( \% )}\end{array}$ & $\begin{array}{c}\mathbf{2 0 0 3 - 2 0 0 4} \\
\mathbf{( \% )}\end{array}$ \\
\hline Fever & 100 & 100 & 100 & $101(100.0)$ \\
Tourniquet test (+) & 55 & 69 & 64 & $11(100.0)^{*}$ \\
Petechie & 79 & 69 & 78 & $71(71)$ \\
Hematemesis & 19 & 8 & 14 & $7(7)$ \\
Melena & 18 & 7 & 16 & $2(2)$ \\
Abdominal pain & 37 & 52 & 62 & $48(48)$ \\
Hepatomegaly (>2cm) & 53 & 49 & 73 & $47(47)$ \\
Seizure & 8 & 2 & 8 & $4(4)$ \\
Thrombocytopenia & 81 & 59 & 77 & $95(94)$ \\
Shock & 64 & 28 & 16 & $59(58)$ \\
Vomiting & 27 & 71 & 35 & $67(66)$ \\
Diarrhea & 5 & 24 & 23 & $24(24)$ \\
Epistaxis & - & - & - & $10(10)$ \\
Hemoconsentration & - & - & - & $87(87)$ \\
Coryza & - & - & - & $30(30)$ \\
Cough & - & - & - & $40(40)$ \\
Pleural Effusion & - & - & - & $38(100.0)^{* *}$ \\
Altered of consciousness & - & - & - & $14(14)$ \\
\hline
\end{tabular}

${ }^{*} \mathrm{n}=11 ;{ }^{* *} \mathrm{n}=38$

TABLE 3. Univariate ANALYSIS OF RISK FACTORS

\begin{tabular}{|c|c|c|c|c|c|}
\hline Variable & $\begin{array}{c}\text { Shock (+) } \\
\text { n (\%) }\end{array}$ & $\begin{array}{c}\text { Shock (-) } \\
\text { n (\%) }\end{array}$ & $\mathbf{R R}$ & $95 \% \mathrm{Cl}$ & $\mathbf{P}$ \\
\hline \multicolumn{6}{|l|}{ Age (years) } \\
\hline$<5$ & $21(62)$ & $13(38)$ & 0.9 & $0.6-1.3$ & 0.63 \\
\hline$\geq 5$ & $38(57)$ & $29(43)$ & & & \\
\hline \multicolumn{6}{|l|}{$\operatorname{Sex}$} \\
\hline Female & $33(61)$ & $21(39)$ & 0.9 & $0.6-1.3$ & 0.55 \\
\hline Male & $26(55)$ & $21(45)$ & & & \\
\hline \multicolumn{6}{|l|}{ Nutritional status } \\
\hline Well-nourished & $22(55)$ & $18(45)$ & 0.9 & $0.6-1.3$ & 0.57 \\
\hline Under-nourished & $37(61)$ & $24(40)$ & & & \\
\hline \multicolumn{6}{|l|}{ Abdominal pain } \\
\hline Yes & $31(65)$ & $17(35)$ & 1.2 & $0.8-1.7$ & 0.23 \\
\hline No & $28(53)$ & $25(47)$ & & & \\
\hline \multicolumn{6}{|c|}{ Temperature(axilla) } \\
\hline$\geq 38^{\circ} \mathrm{C}$ & $23(50)$ & $23(50)$ & 0.8 & $0.5-1.1$ & 0.12 \\
\hline$<38^{\circ} \mathrm{C}$ & $36(66)$ & $19(35)$ & & & \\
\hline \multicolumn{6}{|l|}{ Hepatomegaly } \\
\hline Yes & $40(85)$ & $7(15)$ & 2.4 & $1.6-3.5$ & $<0.001$ \\
\hline No & $19(35)$ & $35(65)$ & & & \\
\hline \multicolumn{6}{|l|}{ Hematocrit (vol\%) } \\
\hline$\geq 41.5$ & $45(68)$ & $21(32)$ & 1.7 & 1.1-2.6 & 0.006 \\
\hline$<41.5$ & $14(40)$ & $21(60)$ & & & \\
\hline \multicolumn{6}{|l|}{ Leukocyte (/ml) } \\
\hline$<5000$ & $22(50)$ & $22(50)$ & 0.8 & $0.5-1.1$ & 0.13 \\
\hline$\geq 5000$ & $37(65)$ & $20(35)$ & & & \\
\hline \multicolumn{6}{|l|}{ Platelet count $(/ \mu \mathrm{l})$} \\
\hline$<50000$ & $54(75)$ & $18(25)$ & 4.4 & $1.9-9.8$ & $<0.001$ \\
\hline$\geq 50000$ & $5(17)$ & $24(83)$ & & & \\
\hline
\end{tabular}

Table 4. Multivariate logistic regression analysis of RISK FACTORS

\begin{tabular}{lccccc}
\hline \multicolumn{1}{c}{ Variable } & B & S.E. & Wald & df & Sig. \\
\hline Hepatomegaly & 2.279 & 0.577 & 15.595 & 1 & 0.000 \\
Thrombocytopenia & 2.589 & 0.639 & 16.411 & 1 & 0.000 \\
Constant & -2.435 & 0.621 & 15.374 & 1 & 0.000 \\
\hline
\end{tabular}

\section{Discussion}

Dengue hemorrhagic fever is primarily disease of children under 15 years in hyperendemic areas. $3,4,19$ This study showed that DHF is more frequent to be found in children aged 6-10 years. The result was consistent with that reported by Harris, ${ }^{15}$ Sukrii, ${ }^{20}$ and Kabilan. ${ }^{21}$ On the other hand, Corwin ${ }^{22}$ reported that the incidence was higher in age between 9-10 years old. This difference presumably was caused by the fact that our study population was limited only to pediatric ward's patients.

Male and female ratio was nearly equal in our study, likewise there was also no different between both sexes in shock cases. The result was consistent with that reported by Narayanan, ${ }^{13}$ Gayatri, ${ }^{18}$ Sukri, ${ }^{20}$ and Harun. ${ }^{22}$

Good nutritional status seems related to good immune response that can lead to severe DHF. Dengue hemorrhagic fever is most likely to develop in immunocompetent and well-nourished girl.3,12,22 On the contrary, this study found shock cases more prevalent among undernourished male and female. Bachtar ${ }^{23}$ has concluded that nutritional status has no correlation with severe cases and shock can be also affected in malnourished child. These differences seem to be related to lower socioeconomic status of patients who came to our hospital.

Out of all hospitalized patient, more than a half (58.4\%) developed shock. The high incidence was presumably caused by the outbreak occurred at that time and only patients with severe cases were hospitalized. 
Thirty-four $(33.7 \%)$ of shock patients in our study had a maximum temperature $<38^{\circ} \mathrm{C}$, only a small number had maximum temperature $>40^{\circ} \mathrm{C}$. Hovarth ${ }^{24}$ observed that $85 \%$ patients had maximum temperature $<38^{\circ} \mathrm{C}$, while Gayatri ${ }^{18}$ found that the temperature between $38.1-39^{\circ} \mathrm{C}$ was more common in shock patients. Apparently, most of our patients were hospitalized nearly the time of defervescence, thus the real maximum temperature could not be detected. In the present study, duration time of fever before admission was fourth day (mean 4.3 day, SD 0.9). Patients with shock have already got fever for 5 days before admission (mean 4.6 days, SD 0.7).

A high hematocrit value is associated with plasma leakage that plays an important role in the pathogenesis of shock. Hematocrit value among DHF patients can reach more than $40 \mathrm{vol} \%$ even as high as 50-60 vol\%. ${ }^{25}$ In our study, hematocrit value between 46-50 vol\% was noted more frequently in shock patients, while Gayatri ${ }^{18}$ reported a large part of shock cases had hematocrit value between 40-45 vol\%. However, the criteria of increased hematocrit value (20\%) is often difficult to be implemented since baseline value is not always available. Therefore, we need to carry out a study to determine the cut off point for hematocrit value in our hospital.

Bleeding manifestations are associated with higher mortality in dengue shock patients. Hemorrhage was consequence of either a more pronounce degree of thrombocytopenia, platelet dysfunction, or disseminated intravascular coagulation. ${ }^{26-29}$ Petechie was the most common bleeding manifestation in our study. Meanwhile, we found that most of shock patients had low platelet count $(<20000 / \mu \mathrm{l})$ and hematemesis or melena occurred only in such conditions. This finding supported by other study which concluded that the risk of spontaneous bleeding was associated with a platelet count $<20000 / \mu 1$ and patients with platelet counts $<50000 / \mu$ l have been reported to have six-fold increase in mortality. ${ }^{29}$ Nevertheless, other factors like vasculopathy and coagulopathy also play role in the pathogenesis of bleeding manifestation.

There were some alterations in clinical spectrum among DHF patients in our hospital compared to the previous ten-year period. There was an increase number of patients with thrombocytopenia, vomiting, diarrhea and shock, in contrary with other symptoms such as bleeding manifestation, abdominal pain, hepatome- galy, and seizure. Shock cases seem to be significantly increased in our study; it might be due to the status of our hospital as a referral hospital.

In this study we found unusual clinical manifestation, i.e. altered consciousness with seizure. It has to be our concern especially in hyperendemic area like in Indonesia. Other viral diseases could be easily misdiagnosed as DHF grade I and II. Other clinical findings such as diarrhea and flu-like syndrome that usually found in dengue fever was also found in our study.

Our data demonstrated that hematocrit value was associated with shock incidence in univariate but not in multiple logistic regression analysis. In our study, multiple logistic regression analysis showed that only platelet count and hepatomegaly were significantly associated with the development of shock. In contrast, Triono's study, ${ }^{16}$ used hepatomegaly, hematocrit value $>41.5 \mathrm{vol} \%$, thrombocytopenia $\leq 100000 / \mathrm{ml}$, and leucopenia as prognostic factors for the severity of dengue. Suparyatha ${ }^{17}$ reported that abdominal pain, hepatomegaly, ascites, haemoglobin, hematocrit, and thrombocyte were predictive factors of shock.

The present study has several limitations. It was retrospective study that depended entirely on the completeness and quality of data. The missing data might be useful for this study. The other limitations were selection bias in our patients because only patients who underwent serologic evaluation were included in this study with varied examiners.

Our findings suggested that there were alteration on clinical features in our hospital between years 2003 . 2004 , compared to the previous years wherein number of shock cases seems to be increased. Platelet count

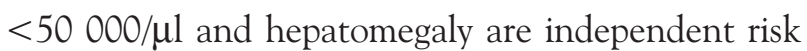
factors for shock among DHF patients.

\section{References}

1. World Health Organization. Dengue hemorrhagic fever: Diagnosis, treatment, prevention, and control. Geneva: WHO; 1997. p. 1-83.

2. Kautner I, Robinson MJ, Kuhnle U. Dengue virus infection: Epidemiology, pathogenesis, clinical presentation, diagnosis, and prevention. J Pediatr 1997; 131:515-24.

3. Gibbons R, Vaughn DW. Dengue: An escalating problem. BMJ 2002;324:1563-6. 
4. Shepherd S, Hinfey P. Dengue fever. Available from: URL: http://www.emedicine.com/emerg/topic124.htm.

5. Suroso T, Achmad H, Imran A. Dengue hemorrhagic fever outbreaks in Indonesia 1997-1998. Dengue Bull 1998;22:38-44.

6. Tumbelaka AR. Diagnosis demam dengue/demam berdarah dengue. In: Harun SR, Satari HI, editors. Demam berdarah dengue. Naskah lengkap pelatihan bagi dokter spesialis anak dan dokter spesialis penyakit dalam dalam tatalaksana kasus demam berdarah dengue. Jakarta: Balai Pustaka FKUI; 1999. p. 73-9.

7. Suroso T, Harun SR, Wuryadi S, Simanjuntak C, Umar AI, Pitoyo PD, et al. Pencegahan dan penanggulangan penyakit demam dengue dan demam berdarah dengue. Jakarta: Depkes RI; 2000. p. 105-14.

8. Harun SR, Soegijanto S, Suroso T. Tatalaksana demam dengue/demam berdarah dengue pada anak. In: Harun SR, Satari HI, editors. Demam berdarah dengue. Naskah lengkap pelatihan bagi dokter spesialis anak dan dokter spesialis penyakit dalam dalam tatalaksana kasus demam berdarah dengue. Jakarta: Balai Pustaka FKUI; 1999. p. 82-137.

9. Harun SR, Purwanto SH, Chatab F. Dengue shock syndrome, clinical manifestations, management, and the outcome. In: Soegijanto S, Poernomo B, Hargono R, Notosudirjo I, Probohoesodo S, Rantam FA, et al, editors. Proceeding of International seminar on dengue fever/dengue hemorrhagic fever. New strategy in controlling and prevention of dengue fever/dengue hemorrhagic fever in South-East Asia; Surabaya: October 28-29, 1999. p. 43-9.

10. Juffrie M, Meer Vande GM, Haasnoot K, Groen J, Sutaryo, Hack CE, et al. Early clinical and laboratory indicators for development of shock in children with dengue virus infection. Crit Care \& Shock 1999;4:201-7.

11. Cam BV, Fonsmark L, Hue NB, Phuong NT, Poulsen A, Heegaard ED. Prospective case control study of encephalopathy in children with dengue hemorrhagic fever. Am J Trop Med Hyg 2001;65:848-51.

12. Vaughn DW, Green S, Kalayanarooj S, Innis BL, Nimmannitya S, Suntayakorn S, et al. Dengue viremia titer, antibody response pattern, and virus serotype correlate with disease severity. J Infect Dis 2000;181:2-9.

13. Narayanan M, Aravind MA, Thilothammal N, Prema $\mathrm{R}$, Rex CS, Sargunam, et al. Dengue fever epidemic in Chennai: A study of clinical profile and outcome. Indian Pediatrics 2002;39:1027-33.

14. Guzman MG, Kouri G. Advances in dengue diagnosis. Clin Diagn Lab Immunol 1996;3:621-27.
15. Harris E, Videa E, Perez L, Sandoval E, Tellez Y, Perez $\mathrm{MA}$, et al. Clinical, epidemiologic and virologic features of dengue in the 1998 epidemic in Nicaragua. Am J Trop Med Hyg 2000;63:5-11.

16. Triono A. Faktor prognostik memberatnya demam dengue dan demam berdarah dengue di instalasi kesehatan anak RS dr. Sardjito [thesis]. Yogyakarta: Gadjah Mada University; 2004.

17. Suparyatha IBG. Faktor-faktor prediktor renjatan pada demam berdarah dengue [preliminary report]. Denpasar: Udayana University; 2002.

18. Gayatri P. Faktor-faktor prognosis pada demam berdarah dengue [thesis]. Jakarta: University of Indonesia; 1997.

19. Guzman MG, Kouri G. Dengue: An update. Lancet Infect Dis 2002;2:33-42.

20. Sukri NC, Laras K, Wandra T, Didi S, Larasati RP, Rachdyatmaka JR, et al. Transmission of epidemic dengue hemorrhagic fever in easternmost Indonesia. Am J Trop Med Hyg 2003;68:529-35.

21. Kabilan L, Balasubramanian S, Keshava M, Thenmozhi V, Sekar G, Tewari SC, et al. Dengue disease spectrum among infants in the 2001 dengue epidemic in Chennai, Tamil Nadu India. J Clin Microbiol 2003;41:3919-21.

22. Harun SR. Telaah endotoksemia pada perjalanan penyakit demam berdarah dengue, perhatian khusus pada syok, produksi TNF-a, interleukin-6, dan sebagai faktor prediktor demam berdarah dengue berat [dissertation]. Jakarta: University of Indonesia; 1996.

23. Bachtar E. Status gizi anak penderita demam berdarah dengue [thesis]. Jakarta: University of Indonesia; 1990.

24. Horvath R, McBride WJH, Hanna JN. Clinical features of hospitalized patients during dengue-3 epidemic in Far North Queensland 1997-1998. Dengue Bull 1999;23:20-24.

25. Sutaryo. Dengue. 1st ed. Yogyakarta: Penerbit Medika FK-UGM; 2004.

26. Lei HY, Yeh TM, Liu HS, Lin YS, Chen SH, Liu CC. Immunopathogenesis of dengue virus infection. J Biomed Sci 2001;8:377-88.

27. Juffrie M, Haasnoot K, Thijs LG. Dengue virus infection and dengue hemorrhagic shock. Crit Care \& Shock 2000;3:139-45.

28. Gomber S, Ramachandran VG, Kumar S, Agarwal KN, Gupta P, Dewan DK. Hematological observation as diagnostic markers in dengue hemorrhagic fever: A reappraisal. Indian Pediatrics 2001;38:477-81.

29. Shivbalan S, Anandnathan K, Balasubramanian S, Datta M, Amalraj E. Predictors of spontaneous bleeding in dengue. Indian Pediatrics 2004;71:33-6. 